\title{
PENGEMBANGAN PERANGKAT PEMBELAJARAN MATERI BANGUN RUANG SISI LENGKUNG BERBASIS ETNOMATEMATIKA BERBANTUAN APLIKASI GOOGLE FORM SEBAGAI PENUNJANG PEMBELAJARAN DARING
}

\author{
Sofhia Ma'rifatuz Zahro ${ }^{1 *}$, Sunardi ${ }^{2}$, Abi Suwito $^{2}$, Susanto $^{2}$, Lela Nur Safrida ${ }^{2}$ \\ Program Studi Pendidikan Matematika, FKIP, Universitas Jember \\ Jalan Kalimantan 37 Kampus Tegalboto, Jember 68121 \\ E-mail: sofhiamarifatuz@gmail.com
}

\begin{abstract}
This research aims to know the process and the result of the development of Mathematics Learning Instruments for ethnomathematics based curved space chapter with the help of the Google Form aplication as a support for online learning. This research is development research. Learning instruments development model refers to four $D$ models. The product of this research are teaching materials, student's worksheet, and evaluation test. This research took place at IX A of junior high school 2 Puger, Jember with consist 36 students. The data collection methods used in this research are the interview, test, and questionnaire. Based on data analysis, this research has three result. First, the learning instrument developed have valid criteria. Secondly, the learning instrument developed have practical criteria based on interview and student's responses. Third, the learning instrument developed have effective criteria based on student's score and student's positive responses.
\end{abstract}

\section{Keyword: Learning Instrument, Ethnomathematics, Google Form, Online} Learning.

\section{PENDAHULUAN}

Wuhan, China merupakan daerah ditemukannya Covid-19 untuk pertama kali, namun sekarang telah menyebar luas di seluruh dunia termasuk Indonesia. Covid-19 dapat dengan mudah menyebar ke individu lain baik melalui percikan cairan atau lendir maupun melalui udara. Pencegahan yang bisa dilakukan adalah meningkatkan imunitas tubuh dengan cara mengkonsumsi makanan yang sehat, hindari makanan yang masih mentah atau kurang matang, olahraga dengan teratur, istirahat yang cukup, menggunakan masker ketika di keramaian maupun di tempat yang berisiko, rajin cuci tangan, serta langsung berobat jika merasa sakit [1].

Salah satu dampak yang ditimbulkan dari pandemi Covid-19 adalah belajar dari rumah atau daring. Namun, pembelajaran daring yang berkepanjangan menimbulkan kekhawatiran bagi guru, siswa, orang tua, dan masyarakat yang peduli terhadap pendidikan. Peserta didik tidak bisa dibiarkan saja libur panjang hingga pandemi berakhir, oleh karena itu sistem pembelajaran hybrid yang mengombinasikan antara Pembelajaran Jarak Jauh (PJJ) dengan PTM harus dilakukan meskipun ditengah pandemi [2]. Kekhawatiran yang dimaksudkan sebagai efek pembelajaran daring yang

\footnotetext{
${ }^{1}$ Mahasiswa S1 Prodi Pendidikan Matematika FKIP Universitas Jember

${ }^{2}$ Dosen Prodi Pendidikan Matematika FKIP Universitas Jember
} 
berkepanjangan adalah hilangnya kemampuan dan pengalaman belajar (learning loss) terutama pada siswa yang kesulitan mengikuti pembelajaran jarak jauh (PJJ) serta pada mata pelajaran yang membutuhkan praktek dan penjelasan lebih dari guru yaitu mata pelajaran saintek.

Matematika adalah salah satu mata pelajaran saintek yang membutuhkan perhatian lebih. Matematika mengandung rumus dan perhitungan yang tidak dapat dianggap remeh karena tidak mudah dipahami secara mandiri tanpa bantuan orang lain atau guru. Matematika akan lebih mudah dipahami jika dikaitkan dengan kebudayaan atau kehidupan sehari-hari siswa. Kebudayaan merupakan pedoman dalam menjalani kehidupan, sementara pendidikan merupakan cara paling efektif dalam menjaga dan melestarikan kebudayaan, karena salah satu peran pendidikan yaitu membentuk karakter seseorang untuk berbudaya [3]. Oleh karena itu, kebudayaan dan pendidikan yang salah satunya adalah bidang matematika keduanya saling mendukung, melengkapi, dan menguatkan satu sama lain serta menjadi bagian yang tidak dapat dipisahkan.

Cabang matematika yang erat hubungannya dengan kehidupan sehari-hari yaitu ilmu geometri. Geometri merupakan ilmu matematika yang mempelajari mengenai bangun, pola, ukuran, dan bentuk benda-benda [4]. Geometri memiliki cabang diantaranya bangun datar dan bangun ruang. Contoh bangun datar adalah persegi, segitiga, lingkaran, trapesium, dan layang-layang. Bangun ruang dibagi menjadi dua yaitu bangun ruang sisi datar dan bangun ruang sisi lengkung. Contoh bangun ruang sisi datar adalah kubus, balok, prisma, dan limas. Sedangkan contoh bangun ruang sisi lengkung adalah kerucut, tabung, dan bola. Sebagian besar siswa kurang menyukai materi geometri, hal ini dikarenakan kurangnya pemahaman dan penalaran konsep siswa serta siswa dituntut untuk membayangkan suatu bangun agar bisa memecahkan soal. Kurangnya pemahaman dan penalaran konsep siswa ini juga didasari atas proses berpikir masingmasing siswa. Untuk meningkatkan pemahaman dan proses berpikir siswa diperlukan perangkat pembelajaran yang mendukung.

Perangkat pembelajaran merupakan segala hal pendukung pembelajaran yang disusun oleh guru baik secara individu maupun kelompok dan ditujukan untuk memperoleh hasil sesuai dengan yang diharapkan dari pelaksanaan dan evaluasi pembelajaran yang dilakukan secara sistematis [5]. Perangkat pembelajaran yang dikembangkan dalam penelitian ini berupa bahan ajar, lembar kerja siswa (LKS), dan tes hasil belajar siswa (THB). Situasi pandemi saat ini mengharuskan pendidik untuk membuat perangkat pembelajaran yang memadai baik dalam segi offline dan online.

Salah satu aplikasi yang mendukung pembuatan perangkat pembelajaran secara online yang mudah dioperasikan, sederhana dalam pengoperasiannya, dan gratis adalah Google Form [6]. Google Form merupakan salah satu fitur dari Google Docs yang disediakan oleh Google. Perangkat pembelajaran yang dibuat menggunakan Google Form mengefisiensi waktu karena tidak perlu membagikannya satu persatu apalagi sampai mencetak nya di kertas, namun cukup membagikan link yang disalin dari Google Form yang telah dibuat ke grup media sosial atau media lain dan orang-orang bisa langsung mengisinya secara online.

SMP Negeri 2 Puger merupakan salah satu sekolah di Kabupaten Jember yang menerapkan sistem pembelajaran daring. Pembelajaran daring seperti saat ini menyulitkan siswa untuk memahami materi bahkan mengerjakan soal-soal latihan secara mandiri terutama pada materi geometri yang bersifat abstrak dan membutuhkan visualisasi yang relatif tinggi. Salah satu materi geometri yang ada di SMP adalah bangun ruang sisi lengkung. Berdasarkan hasil wawancara dengan guru mata pelajaran matematika diperoleh informasi bahwa siswa memperoleh materi hanya dari buku paket 
dan dari file yang dikirimkan oleh guru mata pelajaran. Siswa mendapatkan latihan soal dari guru dengan format pdf yang dikirim melalui grup Whatsapp kelas. Pemanfatan aplikasi Google Form dalam pembelajaran yaitu pada ulangan harian, ujian tengah semester, dan ujian semester. Perangkat pembelajaran berbasis etnomatematika berbantuan aplikasi Google Form merupakan salah satu solusi dalam kegiatan pembelajaran daring maupun hybrid dalam masa pandemi saat ini karena dapat diakses dan diisi secara online serta berisi permasalahan yang berkaitan dengan kehidupan seharihari sehingga dapat lebih menarik minat siswa untuk belajar.

\section{METODE PENELITIAN}

Jenis penelitian ini adalah penelitian pengembangan (research and development). Penelitian pengembangan merupakan kegiatan penelitian dasar dengan tujuan untuk mendapatkan informasi yang dibutuhkan lalu dilanjutkan dengan kegiatan pengembangan untuk menghasilkan produk tertentu serta mengkaji keefektifan produk tersebut [7]. Proses pengembangan perangkat pembelajaran materi bangun ruang sisi lengkung berbasis etnomatematika berbantuan aplikasi Google Form sebagai penunjang pembelajaran daring mengacu pada four D models (model 4-D). Model 4-D terdiri atas tahap pendefinisian (Define), perancangan (Design), pengembangan (Develop), dan penyebaran (Disseminate). Produk pengembangan perangkat pembelajaran yang dihasilkan yaitu bahan ajar, Lembar Kerja Siswa (LKS), dan Tes Hasil Belajar (THB). Proses pengembangan perangkat yang dilakukan adalah validasi, uji kepraktisan, dan uji keefektifan perangkat pembelajaran.

Tahap pendefinisian terdiri dari lima langkah yaitu analisis awal-akhir, analisis siswa, analisis konsep, analisis tugas, dan perumusan tujuan pembelajaran. Kegiatan yang dilakukan pada langkah analisis awal-akhir adalah melakukan wawancara terhadap guru mata pelajaran matematika kelas IX yaitu Bapak Wiji Harnowo, S.Pd., M.Pd. untuk mengidentifikasi masalah yang sedang terjadi dalam proses pembelajaran, mengetahui kondisi siswa, dan model maupun jenis perangkat pembelajaran yang pernah diberikan kepada siswa. Kegiatan yang dilakukan pada langkah analisis siswa yaitu merumuskan permasalahan yang dihadapi oleh siswa dalam pembelajaran. Informasi mengenai permasalahan siswa diperoleh melalui wawancara yang telah dilakukan sebelumnya, yaitu siswa merasa kesulitan untuk mengikuti pembelajaran daring terutama pada mata pelajaran matematika materi bangun ruang sisi lengkung. Siswa memperoleh materi hanya dari buku paket dan dari file yang dikirimkan oleh guru mata pelajaran, serta untuk latihan soal guru membagikan dalam format pdf melalui grup Whatsapp kelas. Berdasarkan pernyataan tersebut dapat disimpulkan bahwa perangkat pembelajaran terutama bahan ajar yang diperoleh oleh siswa masuk dalam kategori minim. Kegiatan peneliti dalam analisis konsep adalah menentukan, menyusun, dan mengidentifikasi materi yang relevan dengan permasalahan yang dihadapi dalam kegiatan pembelajaran, yaitu materi bangun ruang sisi lengkung. Materi dikaitkan dengan kehidupan sehari-hari agar siswa lebih mudah untuk memahami. Kegiatan yang dilakukan dalam analisis tugas adalah membuat lembar kerja siswa dan tes hasil belajar. Lembar kerja siswa diberikan setelah siswa mempelajari materi yang ada pada bahan ajar, sedangkan tes hasil belajar diberikan kepada siswa setelah siswa mengikuti kegiatan pembelajaran menggunakan bahan ajar dan LKS. Langkah terakhir dalam tahap pendefinisian adalah perumusan tujuan pembelajaran. Kegiatan yang dilakukan pada langkah ini yaitu merumuskan tujuan pembelajaran yang didasarkan pada analisis awal-akhir, analisis siswa, analisis konsep, dan analisis tugas serta mengacu pada Kompetensi Inti (KI) dan Kompetensi Dasar (KD) pada materi bangun ruang sisi lengkung. 
Tahap perancangan terdiri atas 4 langkah utama, yaitu penyusunan tes acuan, pemilihan media, pemilihan format, dan perancangan awal. Kegiatan yang dilakukan pada langkah pertama yaitu menyusun Tes Hasil Belajar (THB) materi bangun ruang sisi lengkung berbasis etnomatematika dengan bantuan aplikasi Google Form. Untuk merancang THB dibuat kisi-kisi soal dan rubrik penilaian. THB diberikan kepada siswa untuk mengukur kemampuan siswa dalam memahami materi yang telah disampaikan. Langkah selanjutnya adalah pemilihan media. Tujuan pemilihan media yaitu untuk mengoptimalkan penyampaian materi pembelajaran. Media yang digunakan untuk mendukung kegiatan pembelajaran dalam situasi pandemi saat ini adalah bahan ajar dan Lembar Kerja Siswa (LKS) yang berbasis etnomatematika dan dibuat dengan bantuan aplikasi Google Form. Penerapan materi bangun ruang sisi lengkung di kehidupan seharihari yaitu pada alat dapur dandang dan kubah masjid. Langkah ketiga adalah pemilihan format. Pemilihan format pada bahan ajar dan LKS yang akan dikembangkan adalah yang membantu siswa dan memudahkan siswa untuk dapat tetap mengikuti kegiatan pembelajaran dengan sistem daring di masa pandemi Covid-19. Masalah yang diangkat dalam bahan ajar dan LKS adalah masalah yang erat dengan kehidupan sehari-hari sehingga siswa lebih mudah untuk membayangkan sekaligus memahami materi. Langkah terakhir adalah perancangan awal. Rancangan awal berisi rancangan seluruh kegiatan yang harus dilakukan sebelum uji coba dilaksanakan. Perangkat yang dirancang antara lain bahan ajar, lembar kerja siswa (LKS), dan Tes Hasil Belajar (THB). Hasil tahap ini berupa draft 1 .

Tahap pengembangan terdiri atas dua langkah, yaitu validasi ahli dan uji coba pengembangan. Validasi ahli dilakukan oleh validator yang berkompeten dalam bidang penilaian terhadap perangkat pembelajaran matematika. Validator dalam penelitian ini adalah guru mata pelajaran matematika kelas IX SMP Negeri 2 Puger Bapak Wiji Harnowo, S.Pd., M.Pd. dan dua dosen Program Studi Pendidikan Matematika FKIP Universitas Jember Ibu Rafiantika Megahnia P., S.Pd., M.Si. serta Bapak Dhanar Dwi Hary Jatmiko, S.Pd., M.Pd. Instrumen yang divalidasi dalam penelitian ini yaitu bahan ajar, LKS, THB, pedoman wawancara, dan angket respon siswa. Berdasarkan perhitungan analisis data hasil validasi diperoleh nilai $V_{a}$ berurutan sebesar 3,$83 ; 3,77$; 3,$73 ; 3,87 ; 3,86$ dan dinyatakan valid berdasarkan kriteria validitas instrumen. Setelah perangkat pembelajaran dan instrumen pendukung lainnya divalidasi, maka dilanjutkan ke langkah uji coba. Uji coba pada penelitian ini dilakukan secara online. Uji coba dilaksanakan terhadap 36 siswa kelas 9A SMP Negeri 2 Puger.

Tahap penyebaran bertujuan untuk menyebarluaskan perangkat pembelajaran yang telah dikembangkan. Penyebaran perangkat pembelajaran dilakukan kepada guru SMP Negeri 2 Puger. Selain disebarluaskan pada tempat uji coba, perangkat pembelajaran yang telah dikembangkan juga akan diunggah ke sosial media serta internet seperti blog.

Metode pengumpulan data yang digunakan dalam penelitian ini adalah metode wawancara, tes, dan angket. Instrumen penelitian yang digunakan adalah pedoman wawancara, tes, lembar angket respon siswa, dan lembar validasi. Metode analisis data penelitian ini adalah sebagai berikut.

1. Analisis Kevalidan

Langkah-langkah untuk menguji kevalidan instrumen adalah sebagai berikut [8].

a Melakukan rekapitulasi data penilaian kevalidan yang meliputi aspek $\left(A_{i}\right)$, indikator $\left(I_{i}\right)$, dan nilai $\left(V_{j i}\right)$ untuk masing-masing validator.

b Menghitung rata-rata nilai dari semua validator untuk setiap indikator $\left(I_{i}\right)$ menggunakan rumus berikut 
$I_{i}=\frac{\sum_{j=1}^{2} V_{j i}}{2}$

Keterangan:

$I_{i}:$ nilai indikator ke-i

$V_{j i}$ : data nilai validator ke-j terhadap indikator ke- $i$

$j$ : validator 1 dan 2

$i$ : indikator; $1,2, \ldots$ (sebanyak indikator)

c Menentukan nilai rata-rata untuk masing-masing aspek menggunakan rumus berikut.

$A_{i}=\frac{\sum_{i=1}^{m} I_{i}}{m}$

Keterangan:

$A_{i}$ : rata-rata nilai untuk aspek ke-i

$I_{i}:$ nilai indikator ke-i

$m$ : banyaknya indikator

$i$ : indikator; $1,2, \ldots$ (sebanyak indikator)

d Menentukan nilai rata-rata total semua aspek $\left(V_{a}\right)$ dengan menjumlahkan nilai dan dibagi dengan banyaknya aspek. Secara matematis dapat ditulis sebagai berikut.

$V_{a}=\frac{\sum_{i=1}^{k} A_{i}}{k}$

Keterangan :

$V_{a}:$ nilai rata-rata total untuk semua aspek

$A_{i}$ : rata-rata nilai untuk aspek ke-i

$k$ : banyaknya aspek

e Menentukan tingkat kevalidan dapat dilihat melalui tabel berikut ini.

Tabel 3. 1 Kriteria tingkat kevalidan perangkat pembelajaran

$\begin{array}{lc}\text { Nilai } \boldsymbol{V}_{\boldsymbol{a}} & \text { Tingkat Kevalid } \\ 3 \leq V_{a} \leq 4 & \text { Valid } \\ 2 \leq V_{a}<3 & \text { Cukup valid } \\ 1 \leq V_{a}<2 & \text { Tidak valid }\end{array}$

Sumber (dimodifikasi Hobri, 2010)

Jika semua instrumen yang diuji telah valid sesuai tabel di atas, maka akan dilanjutkan ke tahap selanjutnya, namun jika belum valid maka akan dilakukan revisi dan uji validitas lagi sampai valid.

2. Analisis Kepraktisan

Kepraktisan perangkat pembelajaran diperoleh dari hasil wawancara terhadap guru dan dari data angket respon siswa terhadap penggunaan perangkat pembelajaran hasil pengembangan. Data kepraktisan menggambarkan keterlaksanaan perangkat pembelajaran tersebut. Langkah-langkah yang harus dilakukan untuk menganalisis kepraktisan perangkat pembelajaran berdasarkan hasil respon siswa adalah sebagai berikut.

a Memberikan skor $\left(K_{j i}\right)$ tiap indikator $(i)$ berdasarkan data hasil penilaian yang telah diberikan siswa dengan rincian:

1. skor 1 untuk jawaban STS (sangat tidak setuju)

2. skor 2 untuk jawaban TS (tidak setuju)

3. skor 3 untuk jawaban $\mathrm{S}$ (setuju)

4. skor 4 untuk jawaban SS (sangat setuju)

b Menentukan skor rata-rata tiap indikator $\left(I_{i}\right)$ dari angket jawaban responden menggunakan rumus: 
$I_{i}=\frac{\sum_{j=1}^{n} K_{j i}}{n}$

Keterangan:

$I_{i}=$ skor rata-rata tiap indikator

$K_{j i}=$ skor tiap indikator

$n=$ banyak responden

c Menghitung skor rata-rata total $(R)$ untuk $N$ indikator dengan rumus:

$R=\frac{\sum_{i=1}^{n} I_{i}}{N}$

Keterangan:

$R=$ skor rata-rata total

$I_{i}=$ skor rata-rata indikator ke- $i$

$N=$ banyak indikator

d Mengubah skor rata-rata total $(R)$ menjadi persentase $(P)$ menggunakan rumus:

$P=\frac{R}{S} \times 100 \%$

Keterangan:

$P=$ persentase skor rata-rata

$R=$ skor rata-rata total

$S=$ skor maksimal

e Menyesuaikan persentase skor rata-rata yang didapatkan dengan kriteria skor kepraktisan perangkat pembelajaran. Produk dinyatakan praktis apabila persentase skor yang diperoleh memenuhi kriteria baik atau sangat baik [9]. Kriteria tingkat kepraktisan tersebut dapat dilihat dalam tabel 3.2 berikut.

Tabel 3. 2 Kriteria tingkat kepraktisan perangkat pembelajaran

\begin{tabular}{cc}
\hline Persentase (\%) & Kriteria Kepraktisan \\
\hline$P>95 \%$ & Sangat baik \\
$80 \%<P \leq 95 \%$ & Baik \\
$60 \%<P \leq 80 \%$ & Cukup baik \\
$50 \%<P \leq 65 \%$ & Kurang baik \\
$P \leq 50 \%$ & Sangat kurang baik \\
\hline
\end{tabular}

3. Analisis Keefektifan

Analisis keefektifan dilakukan untuk mengetahui perkembangan yang dialami oleh siswa setelah menggunakan perangkat pembelajaran. Keefektifan perangkat pembelajaran diukur dari data tes hasil belajar dan respon siswa. Perangkat pembelajaran dikatakan efektif jika hasil belajar siswa tuntas secara klasikal dan hasil analisis respon siswa menunjukkan respon positif.

a. Analisis data tes hasil belajar (THB)

Untuk mengetahui keefektifan perangkat pembelajaran, dilakukan analisis mengenai data tes hasil belajar siswa dengan langkah-langkah berikut ini.

1. Melakukan rekapitulasi data nilai masing-masing siswa.

2. Menentukan kategori tetuntasan belajar siswa dengan didasarkan pada Kriteria Ketuntasan Minimal (KKM) yakni sebagai berikut.

a) Siswa dikategorikan tuntas jika nilai yang diperoleh $\geq 75$, dari nilai maksimal 100

b) Siswa dikategorikan belum tuntas jika nilai yang diperoleh $\geq 75$, dari nilai maksimal 100

3. Menghitung jumlah siswa yang termasuk dalam kategori tuntas 
4. Menentukan tetuntasan klasikal dengan kriteria sebagai berikut.

a) Jika jumlah keseluruhan siswa yang telah tuntas $\geq 75 \%$, maka dikategorikan tuntas secara klasikal.

b) Jika jumlah keseluruhan siswa yang telah tuntas $<75 \%$, maka dikategorikan belum tuntas secara klasikal.

b. Analisis data respon siswa

Keefektifan perangkat pembelajaran juga diukur berdasarkan data respon siswa yang diperoleh dari angket respon siswa. Respon siswa dikatakan positif apabila $\geq 75 \%$ siswa merespon dengan memilih jawaban S (setuju) dan SS (sangat setuju) untuk setiap pertanyaan (indikator)

\section{HASIL DAN PEMBAHASAN}

Data yang diperoleh dari langkah uji coba dianalisis guna mengetahui tingkat kepraktisan dan keefektifan perangkat pembelajaran materi bangun ruang sisi lengkung berbasis etnomatematika berbantuan aplikasi Google Form sebagai penunjang pembelajarn daring selama pandemi Covid-19. Data kepraktisan perangkat pembelajaran diperoleh dengan menganalisis data hasil wawancara terhadap guru mata pelajaran matematika kelas 9 dan data respon siswa. Wawancara dilakukan dengan tujuan untuk memperoleh informasi mengenai pembelajaran daring dengan menggunakan perangkat pembelajaran materi bangun ruang sisi lengkung berbasis etnomatematika berbantuan aplikasi Google Form yang telah dikembangkan. Hasil wawancara sebelum pelaksanaan penelitian di SMP Negeri 2 puger yaitu guru belum pernah menggunakan perangkat pembelajaran yang berbasis etnomatematika serta guru belum pernah memanfaatkan Google Form untuk membuat bahan ajar maupun LKS. Pembelajaran cenderung menggunakan buku paket dan dari file yang dikirimkan oleh guru mata pelajaran yang isinya hampir sama dengan materi yang ada di buku paket. Pemberian latihan soal untuk siswa dalam bentuk file pdf yang kemudian dikirim melalui grup Whatsapp kelas. Pemanfatan aplikasi Google Form sendiri dalam pembelajaran yaitu pada ulangan harian, ujian tengah semester, dan ujian semester. Setelah kegiatan penelitian di sekolah dilakukan, guru mata pelajaran matematika menyimpulkan bahwa pelaksanaan kegiatan pembelajaran lebih efektif dan terstruktur serta guru dapat mengetahui mengenai siapa saja siswa yang mengikuti pembelajaran maupun tidak karena nama mereka juga terekam. Perangkat pembelajaran berbasis etnomatematika berbantuan aplikasi Google Form dirasa sangat bermanfaat dalam situasi pandemi saat ini yang mengharuskan serba online. Hal ini sesuai dengan pernyataan bahwa dengan bantuan Google Form, guru lebih hemat waktu dalam membagikan perangkat pembelajaran, mengumpulkan jawaban siswa, dan menganalisis hasil jawaban siswa [6]. Guru juga berpendapat bahwa perangkat pembelajaran berbasis etnomatematika berbantuan aplikasi Google Form terutama pada materi bangun ruang sisi lengkung sangat praktis, yang artinya perangkat pembelajaran bersifat keberlanjutan atau dapat digunakan kembali seiring berjalannya waktu dalam kegiatan pembelajaran meskipun tidak dalam situasi sistem pembelajaran daring. Data kepraktisan selanjutnya diperoleh dari menganalisis data respon siswa. Berdasarkan perhitungan analisis data kepraktisan diperoleh persentase $P$ sebesar $84 \%$ dimana persentase tersebut berada di interval $80 \%<P \leq 90 \%$ yang menunjukkan kategori baik, serta hasil wawancara dengan guru mata pelajaran menyatakan bahwa perangkat pembelajaran sangat relevan untuk dipakai dalam kegiatan pembelajaran terutama dalam masa pandemi Covid-19 saat ini, sehingga perangkat pembelajaran yang dikembangkan dinyatakan praktis. 
Keefektifan perangkat pembelajaran ditentukan berdasarkan hasil analisis 2 macam data, yaitu data hasil belajar dan data respon positif siswa. Perangkat pembelajaran dinyatakan efektif jika hasil belajar siswa tuntas secara klasikal dan respon yang diberikan siswa positif. Data hasil belajar diperoleh dari tes hasil belajar yang telah dilaksanakan. Berdasarkan perhitungan analisis data hasil belajar di kelas 9A dengan 36 siswa diperoleh siswa yang tuntas sebanyak 31 siswa dan siswa yang tidak tuntas sebanyak 5 , sehingga dapat dikategorikan tuntas secara klasikal karena jumlah siswa yang tuntas $\geq 75 \%$ jumlah keseluruhan siswa. Data respon siswa diperoleh dari angket respon siswa. Berdasarkan analisis data respon siswa diperoleh respon siswa memilih jawaban $\mathrm{S}$ (setuju) dan SS (sangat setuju) untuk setiap indikator sebesar $90,51 \%$ dan berada pada $\geq 75 \%$. Sehingga perangkat pembelajaran materi bangun ruang sisi lengkung berbasis etnomatematika berbantuan aplikasi Google Form sebagai penunjang pembelajaran daring dinyatakan efektif. Hal ini sesuai dengan pernyataan bahwa perangkat pembelajaran dikatakan efektif jika ketuntasan belajar secara klasikal dan respon siswa positif [10].

\section{KESIMPULAN}

Berdasarkan hasil penelitian menunjukkan bahwa perangkat pembelajaran materi bangun ruang sisi lengkung berbasis etnomatematika berbantuan aplikasi Google Form sebagai penunjang pembelajaran daring telah dilaksanakan terbukti valid, praktis dan efektif. Perangkat pembelajaran yang dikembangkan memenuhi kriteria efektif berdasarkan hasil analisis THB yang menunjukkan jumlah keseluruhan siswa yang tuntas sebanyak 31 dari 36 siswa dengan persentase $86,11 \%$ sehingga termasuk dalam kriteria tuntas secara klasikal dan hasil analisis respon siswa yang menunjukkan respon positif siswa terhadap perangkat pembelajaran sebesar $90,51 \%$.

\section{DAFTAR PUSTAKA}

[1] Handayani, D., Hadi, D. R., Isbaniah, F., Burhan, E., dan Agustin, H. (2020). Penyakit Virus Corona 2019. Jurnal Respirologi Indonesia, 40(2), 119-129.

[2] Pratama, R. E. dan Mulyati, S. (2020). Pembelajaran Daring dan Luring pada Masa Pandemi Covid-19. Gagasan Pendidikan Indonesia, 1(2), 49-59.

[3] Ulum, B., Budiarto, M. T., dan Ekawati, R. (2017). Etnomatematika Pasuruan: Eksplorasi Geometri untuk Sekolah Dasar pada Motif Batik Pasedahan Suropati. In Seminar Nasional Integrasi Matematika dan Nilai Islam. (1): (70-78).

[4] Bramasti, R. (2012). Kamus Matematika. Surakarta: Aksara Sinergi Media.

[5] Nazarudin. (2007). Manajemen Pembelajaran: Implementasi Konsep, Karakteristik dan Metodologi Pendidikan Agama Islam di Sekolah Umum. Yogyakarta: Teras.

[6] Batubara, H. H. (2016). Penggunaan Gogle Form Sebagai Alat Kinerja Dosen di Prodi PGMI Uniska Muhammad Arsyad Albanjari. Jurnal Pendidikan Dasar Islam, 8(1), 39-50.

[7] Sugiyono. (2009). Metode Penelitian Kuantitatif, Kualitatif, dan R\&D. Bandung: Alfabeta.

[8] Hobri. (2010). Metodologi Penelitian Pengembangan Aplikasi pada Penelitian Pendidikan Matematika. Jember: Pena Salsabila.

[9] Yusuf, A. M. (2015). Asesmen dan Evaluasi Pendidikan: Pilar Penyedia Informasi dan Kegiatan Pengendalian Mutu Pendidikan). Jakarta: Kencana. 
[10] Ose, La. (2017). Pengembangan Perangkat Pembelajaran dengan Pendekatan PMR untuk Meningkatkan Hasil Belajar Siswa. Jurnal Matematika KreatifInovatif, 8(1), 101-108. 